\title{
Molecular-orbital model of heat- induced effective exchange coupling in magnetic multilayers
}

\section{Doctoral Thesis}

Author(s):

Hunziker, Michael

Publication date:

2000

Permanent link:

https://doi.org/10.3929/ethz-a-003913812

Rights / license:

In Copyright - Non-Commercial Use Permitted 
Diss ETH No. 13711

\section{Molecular-Orbital Model of Heat-Induced Effective Exchange Coupling in Magnetic Multilayers}

A dissertation submitted to the

SWISS FEDERAL INSTITUTE OF TECHNOLOGY ZURICH

for the degree of

Doctor of Natural Sciences

presented by

MICHAEL HUNZIKER

Dipl. Natw. ETH

born on April 14 1970

citizen of Kirchleerau, AG (Switzerland)

accepted on the recommendation of

Prof. Dr. H.-C. Siegmann, examiner

Prof. Dr. D. Pescia, co-examiner

Prof. Dr. M. Landolt, co-examiner

Zurich, June 2000 


\section{Abstract}

Heat-induced effective exchange coupling labels the antiferromagnetic coupling between thin ferromagnetic layers separated by an amorphous semiconductor spacer layer. Remarkably, this coupling exists at low temperatures and the coupling strength is found to increase reversibly with rising temperature. These two features are surprising because semiconductors at low temperatures do not provide any free electrons for the transmission of the coupling, and because magnetic effects in general tend to disappear upon heating.

Experimental data measured on the trilayer $\mathrm{Fe} / \mathrm{ZnSe} / \mathrm{Fe}$ are presented. The sign of the coupling is measured by Spin Polarized Secondary Electron Emission. We find antiferromagnetic coupling for spacers with thicknesses around $20 \AA$. For spacer thicknesses below this range, ferromagnetic coupling prevails while above weak or no coupling is observed. Magneto-Optical Kerr Effect allows to directly measure the coupling strength. The coupling strength $J$ is found to reversibly increase upon heating until it saturates at $T \approx 100 \mathrm{~K}$. There, its size is determined to be of the order of $J=10^{-6} \mathrm{Jm}^{-2}$. The described behavior is reversible for temperatures below $T \approx 200 \mathrm{~K}$; above, an irreversible transition takes place. The antiferromagnetic coupling is reduced and at around $T=250 \mathrm{~K}$ it finally disappears. This latter feature and the preparation conditions of the sample lead to the assumption that defects located at the interfaces are the key to the understanding of the coupling mechanism.

In order to give evidence to these interface defect-states, transport measurements are performed along bilayers consisting of Fe and ZnSe. We find zero conductivity for pure ZnSe layers. Thin Fe layers exhibit a finite conductivity with a semiconductor-like behavior. We conclude that Fe grows in grains distributed on the ZnSe surface. Bilayers evaporated at $30 \mathrm{~K}$ exhibit a sharp and large transition at $T \approx 250 \mathrm{~K}$. The behavior of this transition leads to the conclusion that localized electron states are present at the interfaces between Fe and ZnSe electron states which irreversibly disappear at the transition temperature. Analyzing the data within the model of variable range hopping we find a density of defect states $N=1 \times 10^{13} \mathrm{eV}^{-1} \mathrm{~cm}^{-2}$. As a matter of fact, the transitions of the magnetic coupling in $\mathrm{Fe} / \mathrm{ZnSe} / \mathrm{Fe}$ trilayers on one hand and of the conductivity in Fe-ZnSe bilayers on the other occur at the same temperature. This strongly corroborates the conclusion that the coupling mechanism is based on the interaction of interface-defect states. 
Consequently, a molecular-orbital model is devised in order to describe the coupling phenomenon. This model relies on defect states to be present at the two interfaces. The defects are assumed to be shallow donors which overlap across the spacer layer and form large "molecular-orbitals". Because of the Pauli principle the energies of these orbitals depend on the electron-spin configuration. This energy difference eventually drives the exchange coupling. As the energy of antiparallel spin configuration is lower than the one for parallel spins antiferromagnetic coupling prevails. The heat-induced behavior, however, is a consequence of thermal repopulation of the interfering donor states. The results of a approximate calculation, which is based on the molecular-orbital method, are found to very well agree with the experimental findings. 


\section{Zusammenfassung}

Die wärmeinduzierte, effektive Austauschkopplung ist ein magnetischer Kopplungseffekt, den man in Mehrfachschichten findet, deren Schichten wechselweise aus Ferromagneten und amorphen Halbleitern bestehen. Zwei Eigenschaften zeichnen diese Kopplung aus: Die ferromagnetischen Schichten sind untereinander antiferromagnetisch gekoppelt und die Kopplung wird mit steigender Temperatur stärker. Beide Eigenschaften sind bemerkenswert, da die Ferromagneten über eine Zwischenschicht gekoppelt sind, die kaum freie Elektronen enthält und weil magnetische Effekte durch Erwärmen im allgemeinen schwächer werden.

In dieser Arbeit werden die Daten von Kopplungsmessungen vorgestellt, die an einer Fe/ZnSe/Fe-Dreifachschicht, durchgeführt wurden. Das Vorzeichen der Kopplung wurde mit Spinpolarisierter Sekundärelektronen-Emission untersucht. Für Zwischenschichtdicken um $20 \AA$ finden wir antiferromagnetische Kopplung, die für dickere Zwischenschichten schwächer wird und verschwindet. Unterhalb dieses Dickenbereichs finden wir ferromagnetische Kopplung. Die Kopplungsstärke $J$ wird mit Magneto-Optischem Kerr-Effekt gemessen: Durch Heizen nimmt die Kopplungsstärke zu, bis sie um $T \approx 100 \mathrm{~K}$ gesättigt ist; in der Sättigung beträgt ihre Grösse etwa $J=10^{-6} \mathrm{Jm}^{-2}$. Dieses Temperaturverhalten ist bis $T \approx 200 \mathrm{~K}$ reversibel, darüber nimmt die Kopplung irreversibel ab, bis sie bei etwa $T=250 \mathrm{~K}$ verschwindet. Dieser irreversible Übergang sowie die Aufdampfbedingungen für die Probe weisen darauf hin, dass Defekte an den Grenzschichten zwischen Fe und ZnSe für das Verständnis des Kopplungsmechanismus wichtig sind.

Um die Existenz solcher Grenzschicht-Defekte zu beweisen, führen wir Transportmessungen an Doppelschichten aus Fe und ZnSe durch. Reine ZnSe-Schichten leiten überhaupt nicht. Eine dünne Fe-Schicht hingegen verhält sich wie ein amorpher Halbleiter. Wir schliessen daraus, dass Fe auf ZnSe als Verteilung von Fe-Granulat wächst. An Fe-ZnSe-Doppelschichten, die bei $30 \mathrm{~K}$ erzengt worden sind, finden wir bei $T \approx 250 \mathrm{~K}$ einen scharfen Übergang. Das Verhalten dieses Übergangs lässt sich mit der Existenz lokalisierter Elektronenzustände, welche sich an der Grenzschicht zwischen Fe und ZnSe befinden, erklären Elektronenzustände, die bei der Übergangstemperatur irreversibel verschwinden. Eine quantitative Analyse dieser Daten mit dem Variable-Range-Hopping-Modell ergibt eine Defekt-Zustandsdichte von $N=1 \times 10^{13} \mathrm{eV}^{-1} \mathrm{~cm}^{-2}$. Es ist offen- 
sichtlich, dass die magnetische Kopplung in Fe/ZnSe/Fe-Dreifachschichten bei derselben Temperatur verschwindet wie die Grenzschicht-Defekte in einer FeZnSe-Doppelschicht. Diese Tatsache führt zum Schluss, dass die Wechselwirkung zwischen diesen Defektzuständen für das Auftreten der wärmeinduzierten Austauschkopplung verantwortlich ist.

Um das Phänomen der Austauschkopplung zu beschreiben, haben wir das Molekülorbital-Modell entworfen. Die Defekte an den Grenzschichten werden dabei als schwach gebundene Donoren angenommen, welche über die Halbleiterschicht hinweg miteinander interferieren. Die Elektronenzustände der dabei entstehenden Donorpaare bilden grosse "Molekülorbitale", deren Energien wegen des Pauliprinzips von der Elektronen-Spinkonfiguration abhängig sind. Die resultierende Energiedifferenz führt, schliesslich zur Austauschkopplung. Weil die Energie für antiparallele Spinkonfiguration tiefer liegt als diejenige für parallele Spins, wird die antiferromagnetische Kopplung begünstigt. Das wärmeinduzierte Verhalten resultiert nun aus der thermisch angeregten Besetzung der interferierenden Zustände. Die Resultate einer Rechnung in grober Näherung schliesslich, welche auf der Molekülorbital-Methode gründet, stimmen gut mit den experimentellen Daten überein. 